\title{
The Use of Instructional Videos as a Learning Medium for Understanding the Subject of Earthquake Engineering
}

\author{
Jati Sunaryati ${ }^{1, *}$ Ruddy Kurniawan ${ }^{1}$
}

\author{
${ }^{1}$ Civil Engineering Department, Andalas University, Limau Manis Padang \\ *Corresponding author.Email: jati@eng.unand.ac.id
}

\begin{abstract}
This study aims to describe the effectiveness of the use of instructional videos for the Earthquake Engineering course in the Civil Engineering Department, Andalas University. The method of making videos is by editing files using Camtasia Studio. Students who are the target of learning are students in the seventh semester of the Andalas University Civil Engineering Department. The use of learning video-based learning media is to anticipate the impact of the Covid 19 pandemic that is currently hitting. With the making of this video, it is hoped that the learning outcame from the Earthquake Engineering course can still be achieved. The analysis of the use of video in the learning process was carried out by distributing questionnaires after the video was uploaded through Ileran Andalas University. As for the responses from students using the video, $87 \%$ stated that during this pandemic, they agreed to use Ilearn as a learning tool or also function as their classroom. Furthermore, $88 \%$ of them stated that they prefer files in the form of videos as learning media even though they can also receive learning files in the form of PPT and PDF files. However, they do not like online lectures as a learning medium. Furthermore, they stated that $94 \%$ felt the benefits of the video provided. Furthermore, $66 \%$ of students appreciated the accuracy of the video topic with the lecture material, but they stated that the quality of the video still did not get high appreciation. Hopefully this can be a reference for making instructional videos on other topics and objects.
\end{abstract}

Keywords: Earthquake Engineering, learning outcome

\section{INTRODUCTION}

The existence of the Covid-19 virus in 2020 has a tremendous impact in almost all fields, one of which is in the field of education. With the situation of covid-19 virus, the learning process has changed from face-toface to distance learning or online classes. In the situation like this, lecturers and students must remain in a dynamic learning condition so that the learning outcomes objectives are still fulfilled.

This dynamic learning condition is also expected to be fulfilled in the Earthquake Engineering course. This course is in the seventh semester in the Civil Engineering Department, Andalas University. Earthquake Engineering (TSI 429) is a course that discusses the aspects of seismicity and its application in structural engineering. This lecture includes an introduction to the process of an earthquake, how an earthquake is propagating, measuring the magnitude of the earthquake and the earthquake intensity unit. The concept of earthquake-induced building planning includes static and dynamic earthquakes in accordance with the applicable Indonesian National Standards. Applications with software are also provided to facilitate students in the process of understanding structural responses due to earthquakes.

The learning outcomes of this course are:(a) Students are able to explain what an earthquake is and its process, the types of earthquake waves, the location of the epicenter and how to measure the magnitude of the earthquake. (b) Students are able to explain the concept of earthquake resistant structural design. (c) Students are able to calculate and analyze response spectra in various regions and conditions in Indonesia. (d) Students are able to calculate, analyze and design earthquake resistant 
buildings with equivalent static procedures. (e) Students are able to calculate, analyze and design earthquake resistant buildings using response spectra analysis. (f) Students are able to calculate, analyze and design earthquake resistant buildings with time history analysis.

Basically, the earthquake engineering course is a subject that has learning objectives (1) Mastering the theoretical concepts of engineering sciences, engineering mathematics applications, engineering principles, engineering science and engineering design required for system analysis and design mechanical systems, processes, products or components needed, (2) Mastering natural science concepts and principles in applying engineering mathematics, (3) Mastering the principles and techniques of designing mechanical systems, processes or necessary components, (4) Mastering the current principles and issues in economic, social, ecology in general, (5) Mastering knowledge of communication techniques and the latest and latest technological developments in the fields of design, manufacturing processes, and operation and maintenance of mechanical systems and the components required.

Judging from the complex learning outcomes in the Earthquake Engineering course that has been presented above, the application of distance learning supporting technology is very important to be applied during a pandemic like this. On the other hand, technology is increasingly developing, so that students rarely use textbooks and writing books.

One of the learning tools developed is Video Based Learning. This method is considered effective because the human brain is more effective at tracking movement and is attracted to movement, video can make something more interesting than just text. One example, an animation can explain a concept, however difficult the concept will make children and adults sit still to watch. The selection of instructional video media is reinforced by the results of a study that humans process visual information 60,000 times faster than text-based information [1].

\subsection{Research objectives}

The objectives of this study were (1) designing and making instructional videos on the Earthquake Engineering course, (2) analyzing the benefits of these learning videos in the interaction space between lecturers and students.

\section{METHODS}

To achieve the objectives of the research, the method used is

\subsection{Design and create learning videos}

At this step, the things that must be done are:

\subsubsection{Specifically}

Students from this video are seventh semester students of the Civil Engineering Department, Andalas University. This must be used as initial data so that when designing the video material, it is adjusted to the basic supporting knowledge that students must have mastered in order to understand the video that is given later

\subsubsection{Preparation of Video Script}

Manuscript preparation is very important in making videos so that the topics discussed are really focused and well conceptualized. So, it is very important to determine exactly what you want to say in the video. After selecting a focused topic, a relevant and interesting supporting idea is given so that a detailed description of the video topic can be focused. Adjust the type of script with the type of video to be made.

\subsubsection{Determine the Video Type}

The video made can be in the form of a film of yourself while teaching or by conducting experiments and broadcasting live to involve students. Besides that, you can also make a video tutorial or with an animation type.

\subsubsection{Audio}

Background music is very important so that videos don't get boring. Select the sound that is most suitable for enhancing the auditory effect of your video based learning. There are 2 most basic tips for choosing the right music: (a) Adjust the audio volume so it won't interfere with what's being said (b) Choose the sound that can bring the participants to the best mood for studying.

\subsubsection{Make Video Interactive}

Interactivity is the key to successful video learning outcomes. Add icons to make small pop-ups at certain points and give a "click" effect so that it attracts students' attention when using the video. The pop-up is to provide additional information such as interesting facts, tips, funny quotes, or to be redirected to reference material for them to learn more. You can also add simple questionnaires, quizzes, tests or surveys that can engage students.

\subsection{Analysing the benefits of these learning videos in the interaction space between lecturers and students.}

The learning videos were made using Camtasia Studio software (free trial for three month) and uploaded at http://ft.ilearn.unand.ac.id/course/view.php?id=1297. The learning video file is uploaded by clicking on the 
facility as below, or by providing a video link on Google Drive or YouTube channel. (Figure 1)

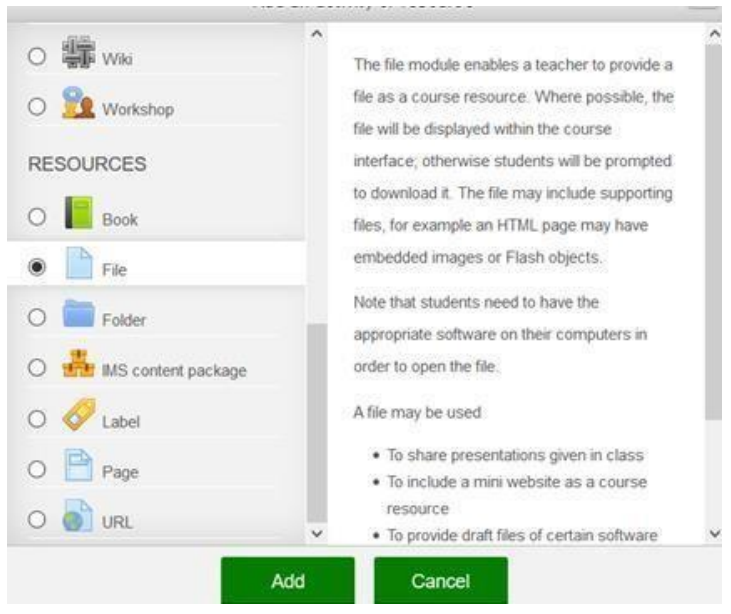

Figure 1. Insert learning content at http://ft.ilearn.unand.ac.id/course/view.php?id=12973

\section{RESULTS AND DISCUSSION}

Based on the need for learning media to achieve the learning outcome objectives, several learning videos have been produced. The learning video for the first cycle is applied to the subtopic Earthquake Map of Indonesia which is part of the Earthquake Engineering course. This video has been distributed to students through the Ilearn media of Andalas University. The duration of this video is 20 minutes.

The study of the application of instructional video files in the Earthquake Engineering course can be seen in the following options:

\subsection{Student views on the use of Ilearn}

Most of the students (87\%) expressed their agreement to use Ilearn media at the time of the current pandemic (see Figure 2). This condition may need to be reviewed if the pandemic period has ended.

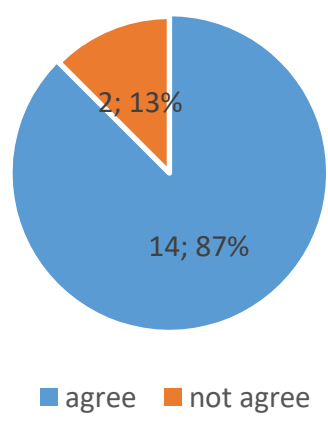

Figure 2 Student opinion about the usefulness of Ilearn

\subsection{Especially for the Earthquake Engineering course, what learning media do you recommend for online learning?}

This question needs to be explored against students because students have different abilities in receiving lessons. From the graph shown in Figure 3, it can be seen that $88 \%$ of students choose video files as the media for learning files, although they still like files with power points $(50 \%)$. What is very important from this data is that it appears that students do not like lectures in the form of online lectures as evidenced by only $13 \%$ of students who still choose this media.

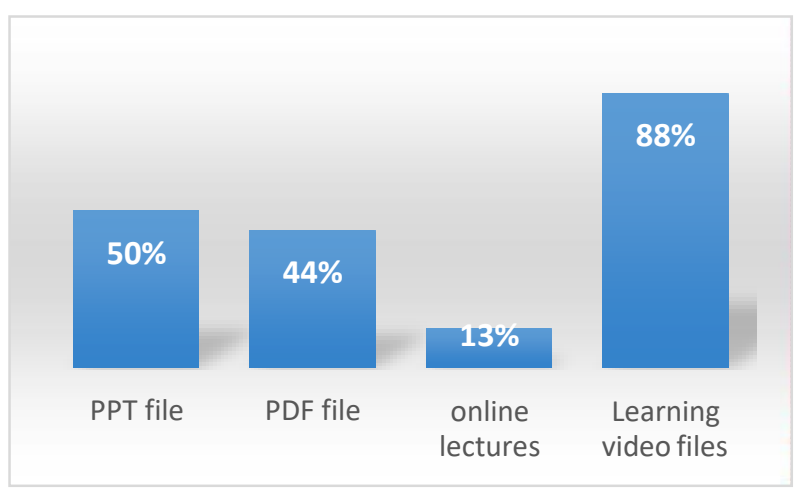

Figure 3 Learning media recommended by students

\subsection{For some of the video material presented in the course, did you find it useful?}

Delivering learning videos to achieve objective learning is certainly a measurable effort so that online lecture design fits the expected criteria. From the processing of the questionnaire data given, it was stated by the students that $94 \%$ of students stated that the learning videos provided were very useful for them (Figure 4).

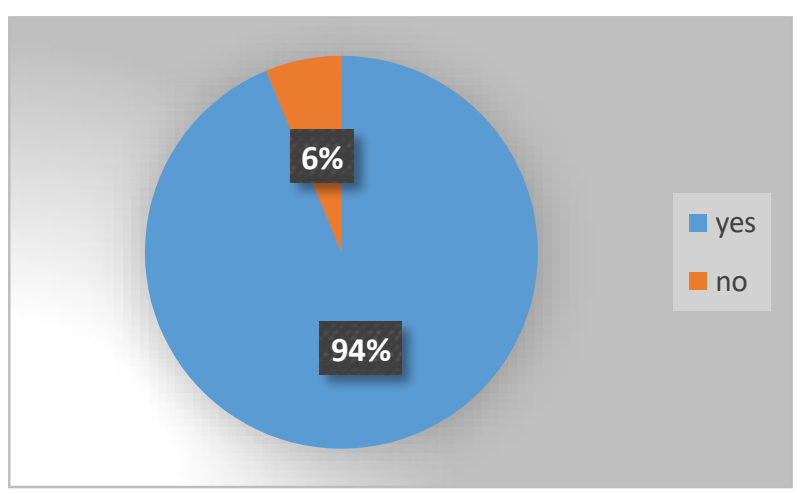

Figure 4 Student opinion which stated that the video given was useful 


\subsection{What do you appreciate from the video given in this course?}

From the information above, it can be understood that the learning video files are in great demand by students. So it must also be studied whether the video files that reach students are well appreciated. This requires a study so that quality videos are always made well. From Figure 5, it can be seen that they appreciate topic suitability as much as $69 \%$, file size that is not too large is $44 \%$ and good sound and video quality is $44 \%$. From this data, skills in making video still need to be improved in order to produce files that are lighter and of higher quality.

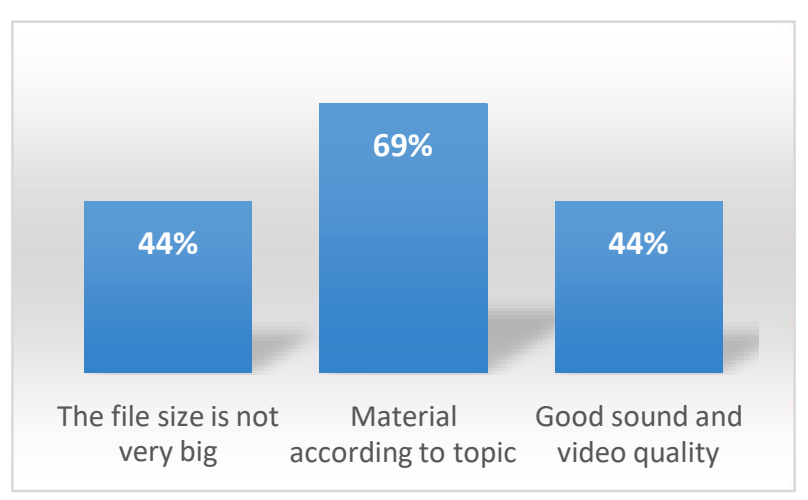

Figure 5 Student awards for video files

\section{CONCLUSION}

From the research that has been done, it can be concluded that during this pandemic, students agreed to the learning process using Ilearn media as their classroom. Of the existing online learning methods, students of the Earthquake Engineering course at the Civil Engineering Department, Andalas University, chose media in the form of learning videos and did not like the learning method in the form of online lectures.

\section{ACKNOWLEDGMENTS}

Many thanks to LP3M Andalas University for funding this research with a contract number T.017/UN.16.18/PT.01.03/2020.

\section{REFERENCES}

[1] Raugust, K. (2006). Teaching the Deaf Through Animation. Retrieved June 19, 2019, from https://www.awn.com/animationworld/teaching - deaf-through-animation

[2] Earthquake Resistance Planning Procedures for Buildings, SNI 1726-2019

[3] Paz, Kim, Y.H (2019), Structural Dynamics: Teory and Computation, Springer, Swizerland

[4] https://www.teachthought.com/learning/12- typesof-blended-learning/ April 21 ${ }^{\text {st }} 2020$ 